\title{
LACK OF STOLBUR TRANSMISSION BY SEEDS IN SOME MOLDAVIAN TOMATO AND PEPPER VARIETIES
}

\author{
Zamorzaeva I., Bahsiev A. \\ Institute of Genetics, Physiology and Plant Protection, Chisinau, Moldova \\ Corresponding author email: izamorz@gmail.com
}

\begin{abstract}
The study of the possibility of stolbur transmission by seeds in some Moldavian tomato and pepper varieties was carried out using molecular diagnostic methods. The lack of the transmission of phytoplasma by seeds was evidenced analysing seedlings growing in the controlled laboratory conditions (thermostat) when the infection by insect vectors was impossible. Moreover, this lack was confirmed by results showing the absence of ' $\mathrm{Ca}$. P. solani' infection in plants analyzed in mid-July of 2020 (stages of 'flowering' or, mainly, 'green fruits') grown in the field or greenhouse.
\end{abstract} tomato, pepper

Keywords: stolbur transmission, 'Candidatus phytoplasma solani', molecular diagnosis,

\section{Introduction}

'Candidatus phytoplasama solani' is one of the worldwide spread phytoplasmas. It is a causal agent of stolbur disease and affects a number of crops including plants from Solanaceae family like potato, tomato and pepper [4, 5]. Some wild plants (bindweed, stinging nettle etc.) act as pathogen reservoirs, being, in fact, intermediate hosts. ' $\mathrm{Ca}$. P. solani' colonizes the phloem of plants and is transmitted by insect vectors as leafhoppers, planthoppers and some others [9]. Additionally, phytoplasmas may also be transmitted from 
infected to healthy plants through the parasitic plant dodder (Cuscuta spp.) [7]. Moreover, the transmission of phytoplasmas by infected seeds is possible sometimes. However, this way of spreading the infection is not common; it has been recorded in a small number of species. In tomato, transmission of phytoplasma infection by seeds has been detected only in some varieties and in limited areas [1].

Symptoms of stolbur infection in solanaceous may be hardly distinguishable being similar with symptoms of other plant diseases caused by viruses or fungi [4]. Specific characteristic of the phytoplasma is a lack of a cell wall that makes it difficult to isolate a pure culture. That is why in 2004 the name 'Phytoplasma' was adopted and is currently of 'Candidatus' status used for bacteria that cannot be cultured [8]. Due to these features it is difficult to identify phytoplasmas. Currently, the most reliable methods of phytoplasma identification are PCR-based techniques including nested-PCR analysis with two pairs of specific primers [2].

Thus, the aim of our research was to study the possibility of ' $\mathrm{Ca}$. P. solani' transmission by seeds in a number of Moldavian tomato and pepper varieties using molecular diagnostic methods.

\section{Materials and methods}

The possibility of phytoplasma transmission by seeds was studied in the four Moldavian tomato varieties (Elvira, Cerasus, Desteptarea, Mary Gratefully) and the four Moldavian pepper varieties (Caolin, Fildes, Excelent, Podaroc Moldovi). Firstly, ' $\mathrm{Ca}$. P. solani' infection was identified in tomato seeds, collected in 2015, and pepper seeds, collected in 2011. Secondly, phytoplasma was analyzed in seedlings growing in thermostat at $+26^{\circ} \mathrm{C}$ for 17 days (pepper) or 20 days (tomato) without the possibility to be infected by insects. Additionally, tomato and pepper plants growing in the field as well as pepper plants cultivating in the greenhouse were assessed for the presence of ' $\mathrm{Ca}$. P. solani' infection in mid-July of 2020. At this period tomato plants were mainly at the stage of green fruits. Pepper plants were mainly at the stages of flowering-green fruits (field) or green fruits (greenhouse).

The phytoplasma presence / absence were identified by nested-PCR analysis with created in IGPPP specific for ' $C a$. P. solani' chaperonin primers [10]. The sampling volume consisted of 7-17 analyzed individuals (seeds, seedlings or plants). Volumes are indicated in Tables 1 and 2. DNA for the molecular diagnosis was isolated by DNA-zol kit from a pool of mixing plants, seedlings or seeds of the pepper. The same method was used in the case of tomato seedlings from thermostat. It is necessary to emphasize that the DNA for nested-PCR analysis was extracted only from cotyledon leaves and stems of plants from thermostat, seed peels have been discarded. The purity of isolated by DNA-zol samples was confirmed by PCR with primers from conservative sequences of ribosomal or pathogenesis related genes of plants. Tomato seeds and plants from the field were analyzed individually using DNA extracted by express alkaline boiling method [3].

\section{Results and discussion}

Identification of ' $\mathrm{Ca}$. P. solani' infection in seeds allowed to determine that this kind of infection was present in seeds of all studied tomato varieties (Table 1). In whole, about a half of analyzed tomato seeds collected in 2015 were infected with phytoplasma (in Cerasus this index was less, but the difference was not significant from the reason of small sampling volume). 
Table 1. Results of ' $\mathrm{Ca}$. P. solani' identification in tomato

\begin{tabular}{|c|c|c|c|c|c|c|}
\hline \multirow[t]{2}{*}{ Variety } & \multicolumn{2}{|l|}{ Seeds } & \multicolumn{2}{|c|}{ Seedlings (thermostat) } & \multicolumn{2}{|c|}{$\begin{array}{l}\text { Plants at the stage } \\
\text { 'green fruits' growing } \\
\text { in the field }\end{array}$} \\
\hline & $\begin{array}{l}\text { S. } \\
\text { volume }\end{array}$ & $\begin{array}{ll}\mathrm{Ca} . & \mathrm{P} . \\
\text { solani } & \end{array}$ & $\begin{array}{l}\text { s. } \\
\text { volume }\end{array}$ & Ca. P. solani & $\begin{array}{l}\text { S. } \\
\text { volume }\end{array}$ & $\begin{array}{l}\text { Ca. } \\
\text { solani }\end{array}$ \\
\hline Elvira & 7 ind & 3 & 17 mix & no & 12 ind & 0 \\
\hline Cerasus & 7 ind & 2 & 17 mix & no & 12 ind & 0 \\
\hline Deste & 7 ind & 4 & 12 mix & no & 12 ind & 0 \\
\hline Mary Gratefully & 0 & $X X$ & 12 mix & no & 12 ind & 0 \\
\hline
\end{tabular}

Abbreviations: ind - DNA for analysis was isolated from individual seeds or plants; mix - DNA for analysis was isolated from mixing plants; $X X$ - assay was not done.

The presence of phytoplasma infection in pepper seeds collected in 2011 was significantly less than in tomato seeds (Table 2). Namely, 'Ca. P. solani' was identified only in seeds of the variety Caolin (Fig. 1). Seeds of the other three studied pepper varieties were not infected with ' $\mathrm{Ca}$. P. solani'. It can be assumed that stolbur in Moldovan varieties of tomato is usually more represented than in pepper. On the other hand, this phenomenon can be explained by different storage periods and different environmental conditions of the year when seeds were collected.

Table 2. Results of ' $\mathrm{Ca}$. P. solani' identification in pepper

\begin{tabular}{|c|c|c|c|c|c|c|c|c|}
\hline \multirow{3}{*}{ Variety } & \multicolumn{2}{|l|}{ Seeds } & \multicolumn{2}{|c|}{$\begin{array}{l}\text { Seedlings } \\
\text { (thermostat) }\end{array}$} & \multicolumn{4}{|c|}{$\begin{array}{l}\text { Plants at stages from 'flowering' to } \\
\text { 'green fruits' }\end{array}$} \\
\hline & \multirow{2}{*}{$\begin{array}{l}\text { s. } \\
\text { volume }\end{array}$} & \multirow{2}{*}{$\begin{array}{l}\text { Ca. } \\
\text { P.solani }\end{array}$} & \multirow{2}{*}{$\begin{array}{l}\text { s. } \\
\text { volume }\end{array}$} & \multirow{2}{*}{$\begin{array}{l}\mathrm{Ca} . \\
\text { P.solani }\end{array}$} & \multicolumn{2}{|c|}{ greenhouse } & \multicolumn{2}{|l|}{ field } \\
\hline & & & & & $\begin{array}{l}\text { s. } \\
\text { volume }\end{array}$ & $\begin{array}{l}\mathrm{Ca} . \\
\text { P.solani }\end{array}$ & $\begin{array}{l}\text { s. } \\
\text { volume }\end{array}$ & $\begin{array}{l}\mathrm{Ca} . \\
\text { P.solani }\end{array}$ \\
\hline $\begin{array}{l}\text { Caolin } \\
\text { Fildes } \\
\text { Excelent } \\
\text { Podaroc } \\
\text { Moldovi }\end{array}$ & $\begin{array}{l}8 \\
8 \\
8 \\
8\end{array}$ & $\begin{array}{l}\text { yes } \\
\text { no } \\
\text { no } \\
\text { no }\end{array}$ & $\begin{array}{l}12 \\
12 \\
8 \\
12\end{array}$ & $\begin{array}{l}\text { no } \\
\text { no } \\
\text { no } \\
\text { no }\end{array}$ & $\begin{array}{l}12 \\
12 \\
12 \\
12\end{array}$ & $\begin{array}{l}\text { no } \\
\text { no } \\
\text { no } \\
\text { no }\end{array}$ & $\begin{array}{l}12 \\
12 \\
12 \\
12\end{array}$ & $\begin{array}{l}\text { no } \\
\text { no } \\
\text { no } \\
\text { no }\end{array}$ \\
\hline
\end{tabular}

Thus, assessing the level of phytoplasma infection in seeds of tomato or pepper was not the main aim of our study. The main aim was to study the possibility of stolbur transmission by seeds in some Moldavian varieties of these species. As shown in Tables 1 and 2, ' $\mathrm{Ca}$. P. solani' infection was not present in any seedlings from thermostat: neither in the four tomato varieties nor in the four pepper varieties. So, the direct evidence of the lack of stolbur transmission by seeds of studied varieties was obtained.

Additionally, the lack of stolbur transmission by seeds was demonstrated by molecular diagnosis of plants in the field (tomato, pepper) and the greenhouse (pepper). ' $\mathrm{Ca}$. P. solani' infection was not identified in plants of both species collected in mid-July of 2020. The results obtained in these experiments were a little surprised taking into account that insect vectors of phytoplasma had free access to plants in the field and, possibly, in the greenhouse. At the same time, the climatic conditions of the year significantly impact to the spread of phytoplasma infection in the field affecting the activity and reproduction of insect vectors. Moreover, the incubation period of phytoplasma infection can be of 1-2 months and is under the control of environmental conditions as temperature, moisture, etc. [6]. A timely treatment of the field with insecticides can also slow down the spread of stolbur. So, we suggest that the 
climatic conditions of 2020, combined with effective agricultural practices, contributed to the absence of ' $C a$. P. solani' in the field in mid-July. In any case, these data can be an additional confirmation of the lack of phytoplasma transmission by seeds.

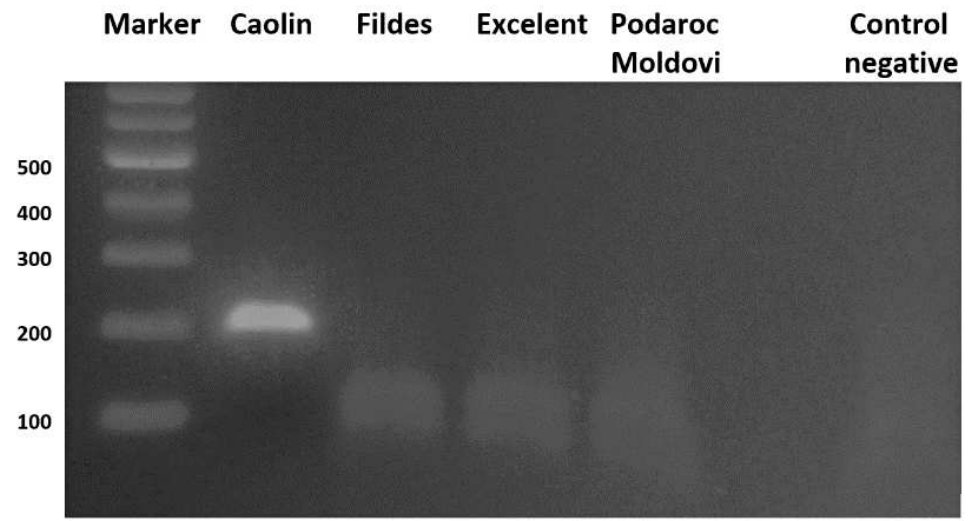

Figure 1. Results of the molecular diagnosis of ' $\mathrm{Ca}$. P. solani' presence in seeds of the four pepper varieties: corresponding fragment 200 b.p. obtained by the electrophoresis of products of nested-PCR (round II) was registered in Caolin variety.

\section{Conclusions}

The main conclusion from the study is that stolbur is not transmitted by seeds in a number of Moldavian varieties of tomato and pepper. Molecular diagnosis allowed to find that seeds of some Moldavian varieties of pepper are less infected with ' $\mathrm{Ca}$. P. solani' compared with tomato seeds. Additionally, it was established that ' $\mathrm{Ca}$. P. solani' infection was not identified in plants of studied species in the field (tomato, pepper) and the greenhouse (pepper) in mid-July of 2020. This can be explained with unfavorable for the activity and reproduction of insect vectors climatic conditions of the year combined with effective agricultural practices.

The authors are grateful to dr. hab. Mihnea N. and dr. Focșa N. for providing plant material for research.

\section{Bibliography}

1. Calari A., Paltrinieri S., Contaldo N., Sakalieva D., Mori N., Duduk B., Bertaccini A. (2011). Molecular evidence of phytoplasmas in winter oilseed rape, tomato and corn seedlings. Bulletin of Insectology, 64 (Supplement), 157-158.

2. Gundersen D.E. \& Lee I.-M. (1996). Ultrasensitive detection of phytoplasmas by nested-PCR assays using two universal primer pairs. Phytopathologia Mediterranea, 35 (3), 144-151.

3. Guo Y., Cheng Z-M., Walla J.A. (2003). Rapid PCR-based detection of phytoplasmas from infected plants. Horticultural Science, 38 (6), 1134-1136.

4. Ivanova G., Mitrev S., Arsov E. (2017). New evidence for the stolbur phytoplasma development in pepper in Republic of Macedonia. Comptes rendus de l'Acad'emie bulgare des Sciences, 70 (11), 1609-1616.

5. Mitrovic J., Pavlovic S., Duduk B. (2013). Survey and multigene characterization of stolbur phytoplasmas on various plant species in Serbia. Phytopathologia Mediterranea, 52 (3), 434-441. 
6. Murral D.J., Nault L.R., Hoy C.W., Madden L.V., Miller S.A. (1996). Effects of temperature and vector age on transmission of two Ohio strains of aster yellows phytoplasma by the aster leafhopper (Homoptera: Cicadellidae). Journal of Economic Entomology, 89, 1223-1232.

7. Pribylova J. \& Spak J. (2013). Dodder transmission of phytoplasmas. Methods in Molecular Biology, 938, 41-46.

8. The IRPCM Phytoplasma/Spiroplasma Working Team - Phytoplasma taxonomy group. (2004). Candidatus Phytoplasma, a taxon for the wall-less, non-helical prokaryotes that colonize plant phloem and insects. International Journal of Systematic and Evolutionary Microbiology. 54 (4), 1243-1255.

9. Weintraub P.G., Beanland L. (2006). Insect vectors of phytoplasmas. Annual Review of Entomology, 51, 91-111.

10. Zamorzaeva I. (2015). Creating primers for detecting phytoplasma infections in tomato plants. In: X International Congress of Geneticists and Breeders, Chisinau, Moldova, 26. 